European Head Office

London

The Macmillan Building

4 Crinan Street

London N1 9XW, UK

Tel +44 (0) 2078434961

Fax +44 (0) 2078434996

e-mail: naturejobs@nature.com

Senior European Sales Manager: Nevin Bayoumi (4978)

UK/ RoW/ Ireland:

Matt Powell (4953)

Andy Douglas (4975)

Frank Phelan (4944)

Netherlands/ Italy/

Iberia/Belgium:

Evelina Rubio Hakansson (4973)

Scandinavia: Sille Opstrup (4994)

France/ Switzerland:

Amelie Pequignot (4974)

Production Manager: Billie Franklin

To send materials use London

address above.

$\mathrm{Tel}+44$ (0) 2078434814

Fax +44 (0) 2078434996

e-mail: naturejobs@nature.com

International

Advertising Coordinator

Hind Berrada (4935)

Naturejobs web development

Tom Hancock

Naturejobs online production:

Ben Lund

European Satellite Office Germany/ Austria:

Patrick Phelan, Odo Wulffen

Tel + $498954905711 /-2$

$\mathrm{Fax}+498954905720$

e-mail: p.phelan@nature.com o.wulffen@nature.com

US Head Office, New York 345 Park Avenue South,

10th Floor, New York, NY 10010-1707

Tel +1 8009897718

$\mathrm{Fax}+18009897103$

e-mail: naturejobs@natureny.com

US Sales Manager: Peter Bless

US Advertising Coordinator:

LindaAdam

Japan Head Office, Tokyo

MG Ichigaya Building (5F),

19-1 Haraikatamachi,

Shinjuku-ku,

Tokyo 162-0841

Tel +81 33267875

Fax +81332678746

Asia-Pacific Sales Director

Hideki Watanabe

e-mail:h.watanabe@naturejp.com

\title{
naturejobs
}

\section{Thinking ahead}

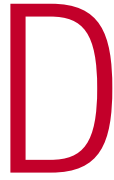

eb Koen tends to have a positive outlook. Vice-president for Career Development Services in Rochester, New York, and a columnist for The Wall Street Journal's online careers section, Koen admits that the scientific job market is tough at the moment. But this is still an opportunity, she told attendees at a career fair sponsored by Naturejobs and the New York Biotechnology Association this month.

Rather than using the economic conditions as an excuse for not getting a new job, Koen told the meeting that scientists should use them as motivation to hone their skills for basic job hunting and career building. These techniques are often neglected in prosperous times, when scientists' core skills are in demand. But when the job market contracts, they can prove to be invaluable.

The key, Koen said, is being proactive about your career think of it as a constant quest to find the best match between your skills, values and interests, and those of an employer. Landing a job where these attributes don't match might help to pay the bills, but it will ultimately result in dissatisfaction. To avoid this, Koen suggested that scientists should keep a career journal. Start with your long-term goals, and then identify short-term goals, such as key projects you want to take on or new skills you want to develop. Also, note any trends that are highlighted by the media.

Being proactive goes beyond writing things down, Koen said, it entails following up on your goals. And it means networking - not by introducing yourself to strangers who you hope might help your career, but by being actively involved in your community. It also means seeking feedback — not just before tenure or during performance reviews, and not just from supervisors, but from colleagues and collaborators at different stages of a project. Perhaps then you will be able to make the most of a depressed job market.

\section{Paul Smaglik}

Naturejobs editor

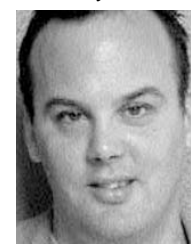

\section{Contents}

\section{CAREERS AND RECRUITMENT}

Proteomics: the land of opportunity

Using proteins to beat the recession

\section{WWW.NATUREJOBS.COM}

Career centre

Information on the scientific job market
Focus

SPOTLIGHT

RECRUITMENT

ANNOUNCEMENTS 